Ann. Zootech., 1980, 29, no h. s., 261-270.

\title{
Influence of energy and protein levels on growth rate, feed efficiency, carcase and meat quality of steers
}

\author{
M.G. KEANE and F.J. HARTE \\ The Agricultural Institute, \\ Grange, Dunsany, Co. Meath, Ireland.
}

\begin{abstract}
The growth pattern of full fed Friesian steers was one of initial increasing rate of gain followed by a declining rate of gain with increasing bodyweight. Differences in ration energy level which had a significant effect on performance had little influence on efficiency or carcase composition of large breed type steers. In a serial slaughter experiment with Friesian steers, the carcases of animals grown on a grass silage/barley diet had more fat and less meat than those grown on a concentrates/chopped straw diet even though both diets were similar in energy content and supported similar levels of performance. There was an interaction between the effects of diet and slaughter weight. At low carcase weights there was no effect of diet on compesition but with increasing carcase weight, the diet effect emerged. A restriction of 20 per cent in feed intake reduced performance, efficiency and carcase fat content.
\end{abstract}

\section{Résumé}

Influence du niveau des apports énergétiques et azotés sur la vitesse de croissance, l'efficacité alimentaire, la qualité des carcasses et des viandes de boufs

La forme de la courbe de croissance de bouvillons Frisons alimentés intensivement à volonté, comporte une phase initiale de croissance accélérée suivie d'une phase où la vitesse de croissance diminue avec l'accroissement du poids vif. Des variations dans le niveau des apports énergétiques des rations ont eu un effet significatif sur la croissance, mais ont peu modifié l'efficacité alimentaire ou la composition des carcasses des bœufs de races de grand format. Dans une expérience comportant des abattages successifs de bœufs Frisons, les carcasses des animaux alimentés avec une ration d'ensilage d'herbe + orge contenaient plus de graisse et moins de viande que celles d'animaux ayant reçu une ration de concentrés associés à de la paille hachée, bien que ces deux rations aient eu la même concentration énergétique et permis les mêmes vitesses de croissance. On a observé une interaction entre les effets de l'alimentation et du poids d'abattage. En effet, l'influence de l'alimentation sur la composition des carcasses n'est pas apparue pour les faibles poids de carcasse mais s'est manifestée lorsque les poids de carcasse ont augmenté. Une réduction du niveau alimentaire de 20 p. 100 a réduit la croissance, l'efficacité alimentaire et la teneur en graisse des carcasses. 


\section{Introduction}

Beef production in Ireland is based on grazed grass and grass conserved as silage or hay. Gradually, ensiling is replacing hay making as the chief method of conservation and this permits the production of a higher quality feed. Protein content of both grass and silage is generally adequate for beef production. Therefore, research on the effects of different protein levels has received less attention than other aspects of cattle nutrition and the subject is not discussed in this paper. The influence of energy levels, mainly in the context of silage quality and concentrate supplementation of silage, is important and has been widely researched. There is also a growing awareness of the need for more information on the composition of our beef carcases (which are predominantly Friesian) and the factors which affect it, with a view to producing carcases in terms of both weight and composition suitable for a wide range of markets.

\section{Review of literature}

Differences in plane of nutrition in early life have little effect on carcase composition when animals which were earlier restricted are allowed an adequate compensatory period of unrestricted recovery before slaughter (WINCHESTER and Howe, 1955 ; Lawrence and Pearce, 1964 ; Drennan, 1979). There is less agreement on the effects of plane of nutrition in the immediate pre-slaughter period on carcase composition. When animals finished on different nutritional levels are slaughtered at the same time, differences in carcase weight could account for part or all of the compositional differences noted. Even at constant carcase weights, however, there are reports showing no effects of pre-slaughter plane of nutrition on carcase composition (KAY et al., 1970; LEVy et al., 1976). On the other hand, some workers have observed carcase differences due to level of feeding before slaughter. In the data of SwAN and LAmMing (1967) percentage carcase bone was positively related and percentages of kidney and carcase fats were negatively related to ration roughage content. The main carcase effect of decreasing the level of energy in the diet was a decrease in fat deposition without any major change in muscle or bone development. Similar conclusions can be drawn from other publications (HENRICKSON et al., 1965 ; BroADBENT, 1977 ; SMITH et al., 1977).

A study on the effects of nutritional level on carcase composition of Holstein steers serially slaughtered (WALDMAN et al., 1971) showed that up to $227 \mathrm{~kg}$ liveweight, composition was not influenced by nutrition but thereafter a high energy ration produced greater amounts of carcase fat than a moderate energy ration. This indicates that there are interactions between the effects of energy level and slaughter weight on carcase composition.

Interactions between the effects of breed type and plane of nutrition on carcase composition are also likely. The greater capacity of the large breeds for proteinogenesis suggests that they could use more feed energy for this function than small breeds. PRIOR et al. (1977) have demonstrated an interaction between breed type and feeding level. An increase in ration energy concentration increased fat gain only in steers of small breed types and therefore affected carcase composition, whereas in steers of the large breed types, it increased both fat and muscle gains 
with the result that overall carcase composition remained unchanged. However, SMITH et al (1977) found no interactions between breed type and ration energy content. Both large and small breed types showed increased fatness independent of carcase weight as a result of increasing the ration energy content.

\section{Experimental results}

\section{Patterns of growth and efficiency}

The general patterns of performance and efficiency of Friesian steers throughout life were reported by HARTE $(1968 a, b)$ when the effects of a period of feed restriction in early life were investigated. Twin Friesian steers individually fed from birth to slaughter at $450 \mathrm{~kg}$ liveweight were used in the experiment. For the first 84 days all animals were fed the same but from then to 200 days one member of each pair of twins was fed a restricted level of concentrates whereas the other had unrestricted access to concentrates. From 200 days to slaughter all animals had unrestricted access to concentrates. Hay was available ad libitum throughout. The performance of the full fed cattle increased gradually to a peak of $1100 \mathrm{~g} / \mathrm{d}$ at 200 days of age and then declined to a low of $400 \mathrm{~g} / \mathrm{d}$ before slaughter. Efficiency of utilisation of metabolisable energy (ME) for liveweight gain $(\mathrm{MJ} / \mathrm{kg})$ decreased throughout life from 40 in calfhood to 500 at slaughter.

Feed restriction from 84 to 200 days did reduce performance during this period but did not affect average daily lifetime performance, carcase weight at slaughter or carcase composition (Table 1). It did, however, lead to a significant but small improvement in efficiency of carcase and lean meat production. From 200 days to slaughter average daily feed and energy intakes were similar for both treatments so the superior performance of the previously restricted cattle resulted in greater efficiency during this period. In subsequent experiments (DRENNAN, 1979) there was no compensation in animals restricted earlier than 200 days of age, but a period of restriction after this was followed by full compensation and there were no differences in carcase composition at constant slaughter weights.

TABEE 1

EFFECT OF RESTRICTED FEEDING FROM 84 TO 200 DAYS OF AGE ON LIFETIME PERFORMANCE, EFFICIENCY AND CARCASE COMPOSITION OF FRIESIAN STEERS

\begin{tabular}{lccc}
\hline & Restricted & Unrestricted & $\pm \mathrm{SE}$ \\
\hline ADG (Lifetime) $\mathrm{g} / \mathrm{d}$ & 630 & 642 & 8 \\
Carcase weight $(\mathrm{kg})$ & 260.4 & 267.0 & 2.55 \\
\& Lean meat & 66.6 & 65.4 & 0.76 \\
\& Fat & 20.5 & 21.5 & 0.95 \\
\& Bone & 12.9 & 13.1 & 0.26 \\
ME/kg Carcase (MJ) & 211 & 224 & $3.70^{*}$ \\
ME/kg Lean meat (MJ) & 327 & 354 & $7.20^{*}$ \\
\hline
\end{tabular}

$\star \mathrm{P}<0.05$ 


\section{Effects of different energy levels}

KEANE (1978) compared the effects of $80: 20$ and $50: 50$ ratios of maize grain to maize silage on performance, efficiency and carcase composition of Charolais and Simmenthal sired steers grown from $208 \mathrm{~kg}$ to slaughter at $550 \mathrm{~kg}$ liveweight. Estimated $\mathrm{ME}$ contents of the high and medium maize diets were 12.9 and $11.7 \mathrm{MJ} / \mathrm{kg}$ dry matter (DM) respectively. Carcase assessment was based on separation of the round (including rump) into fat, lean and bone. Data on feed intake, performance and efficiency are shown in Table 2.

TABLE 2

INTAKES, PERFORMANCE AND EFFICIENCY OF STEERS FED TWO ENERGY LEVELS

\begin{tabular}{lccc}
\hline Grain silage ratio & $80: 20$ & $50: 50$ & \pm SE \\
\hline DMI (kg/a) & 7.56 & 7.76 \\
ADLWG (g) & 1470 & 1340 & 30 ** \\
DM/kg LWG (kg) & 5.14 & 5.79 \\
ME/kg LWG (MJ) & 66.3 & 68.1 & \\
\hline
\end{tabular}

** $P<0.01$

Calculated daily ME intakes were 98 and $91 \mathrm{MJ}$ for the high and medium maize diets respectively. The decrease in the energy content of the ration, due to increasing the silage level from 20 per cent to 50 per cent, resulted in a small increase in DM intake but this did not maintain energy intake. The daily ME intake on the medium grain ration was only 93 per cent of that on the high grain ration and this resulted in a significant reduction in performance of 9 per cent. However, as the reduction in performance was of comparable magnitude to the reduction in energy intake, there was little difference between the two rations in efficiency of energy utilisation.

Composition of the round is shown in Table 3. There was no significant effect of ration energy level on any of the traits. The lack of an energy level effect may have been due to the breed types involved and to use of growth promoters which tend to increase muscle and reduce fat in the carcase.

TABLE 3

COMPOSITION OF ROUND FROM STEERS FED TWO ENERGY LEVELS

\begin{tabular}{lccc}
\hline Grain silage ratio & $80: 20$ & $50: 50$ & $\pm \mathrm{SE}$ \\
\hline Carcase weight $(\mathrm{kg})$ & 330.8 & 331.3 & 1.70 \\
\& Lean & 60.9 & 62.1 & 0.85 \\
F Fat & 22.7 & 21.6 & 1.04 \\
\& Bone & 16.4 & 16.3 & 0.31 \\
\hline
\end{tabular}




\section{Effects of diet type and level of feeding}

A number of studies (MCCARrick, 1966 ; FlynN, 1978) have shown that type of diet (i.e. dry matter content of conserved forage) can affect carcase composition. However, the differences observed in some cases could have been partly due to other factors such as level of feeding, rate of gain or carcase weight at slaughter. In order to assess the relative influence of diet and slaughter weight on carcase composition the following experiment was undertaken using 54 Friesian steers of $315 \mathrm{~kg}$ initial liveweight. Three dietary treatments were imposed on groups of 18 animals (1) 66 per cent grass silage plus 34 per cent barley, (2) 75 per cent concentrates plus 25 per cent chopped straw, (3) 66 per cent grass silage plus 34 per cent barley restricted to 80 per cent of the intake on Treatment 1 . The ratio of concentrates to straw in Treatment 2 was varied slightly from time to time in order to maintain the animals on the same growth curve as those on Treatment 1 . On average the energy concentration of the two diets was similar at $11 \mathrm{MJ} / \mathrm{kg}$ DM. Groups of 6 animals each were slaughtered at 260,300 and $340 \mathrm{~kg}$ carcase weight and the right side from each carcase was separated into fat trim, meat and bone. Initial carcase weight and composition were calculated using data from another experiment. The main objective was to ascertain if diet type $(\operatorname{Tr} 1 \mathrm{v} \operatorname{Tr} 2)$ or level of feeding $(\operatorname{Tr} 1 \mathrm{v}$ $\operatorname{Tr} 3$ ) had an influence on carcase composition and were there interactions with slaughter weight. Daily feed DM and ME intakes for the 3 slaughter intervals are shown in Table 4.

TABLE 4

DAILY FEED DM ( $\mathrm{kg}$ ) AND ME (MJ) INTAKES

\begin{tabular}{lcrrrrrr}
\hline Sl. Int. (kg carcase) & \multicolumn{2}{c}{$150-260$} & \multicolumn{2}{c}{$260-300$} & \multicolumn{2}{c}{$300-340$} \\
& DM & ME & DM & ME & DM & ME \\
\hline Silage/barley & 8.74 & 96 & 10.20 & 112 & 11.00 & 121 \\
Con. (a)/straw & 8.37 & 92 & 10.13 & 111 & 11.69 & 128 \\
Silage/barley (R) & 6.92 & 76 & 8.38 & 92 & 9.14 & 101 \\
\pm SE & 0.09 & & 0.11 & & 0.15 & \\
\hline
\end{tabular}

(a) $88.5 \%$ barley $+10 \%$ soya $+1.58 \mathrm{~min} . / \mathrm{vit} . \mathrm{mix}$
(R) = Restricted

Daily DM and ME intakes increased with increasing weight but declined as a function of liveweight. Daily intakes of the two full fed groups were similar so type of diet did not affect intake. The daily intake of the restricted cattle which was lower than that for the animals full fed the same diet ranged from 79.2 per cent of the latter in the first slaughter interval to 83.1 per cent in the third slaughter interval.

Daily liveweight gains for each slaughter interval are shown in Table 5. There was no significant difference in performance between the animals full fed the silage/barley ration and those fed the concentrates/siraw ration. As intended those restricted fed had a lower overall growth rate. Performance on all thiee treatments declined with time, but this decline was less in the restricted than in the full fed groups. Therefore, restriction of feed intake did not have a constant 
effect on performance over time. Over the first slaughter interval, a restriction of 20 per cent in feed intake reduced performance to 67 per cent of that for the animals full fed the same diet, while over the final slaughter interval the performance of the restricted animals was 91 per cent of that of the full fed group. The probable explanation for this is that at the time the experiment commenced the animals had a capacity for some compensatory growth and early in the experimental period this was exploited more fully on ad libitum feeding than on restricted feeding.

TABLE 5

DAILY LIVEWEIGHT GAINS ( $g$ ) BY SLAUGHTER INTERVAL

\begin{tabular}{lccc}
\hline Sl. Int. (kg carcase) & $150-260$ & $260-300$ & $300-340$ \\
Silage/barley & 1017 & 702 & 519 \\
Con./straw & 979 & 608 & 569 \\
Silage/barley (R) & 684 & 527 & 470 \\
$\pm \mathrm{SE}$ & 22 & 36 & 67 \\
\hline
\end{tabular}

Carcase gains over the three slaughter intervals are shown in Table 6. The main effects of feed and slaughter weight together with the interaction were highly significant. On average, carcase gains constituted 64 per cent of liveweight gains.

TABLE 6

DAILY CARCASE GAINS, (g) BY SLAUGHTER INTERVAL

\begin{tabular}{lccc}
\hline Sl. Int. (kg carcase) & $150-260$ & $260-300$ & $300-340$ \\
\hline Silage/barley & 657 & 430 & 322 \\
Con./straw & 617 & 378 & 369 \\
Silage/barley (R) & 451 & 325 & 296 \\
\pm SE & 16 & 19 & 27 \\
\hline
\end{tabular}

Efficiencies of energy utilisation (MJ ME/ $\mathrm{kg}$ carcase gain) are shown in Table 7. Over the first $110 \mathrm{~kg}$ carcase gain, the full fed cattle produced one $\mathrm{kg}$ carcase per $150 \mathrm{MJ}$ ME consumed, while the restricted fed cattle required 170 MJ ME per $\mathrm{kg}$ carcase gain. Therefore, a restriction of 20 per cent in energy intake reduced carcase gain by 30 per cent and efficiency by 14 per cent over the first slaughter interval. Over the carcase weight interval $260-300 \mathrm{~kg}$ neither type of diet nor level of feeding had a large influence on efficiency which was much inferior to that for the earlier period, while over the final $40 \mathrm{~kg}$ interval of carcase gain, efficiency was better for the restricted cattle than for those full fed the same diet. Average over the entire experimental period efficiency of energy utilisation for carcase gain was similar for the two full fed groups at approximately $220 \mathrm{MJ} \mathrm{ME} / \mathrm{kg}$ carcase and slightly inferior for the restricted animals at $230 \mathrm{MJ} \mathrm{ME} / \mathrm{kg}$ carcase. 
TABLE 7

EFFICIENCY OF UTILISATION OF ME FOR CARCASE GAINS

\begin{tabular}{lccc}
\hline Sl. Int. (kg carcase) & $150-260$ & $260-300$ & $300-340$ \\
\hline Silage/barley & 146 & 261 & 376 \\
Con./straw & 149 & 294 & 347 \\
Silage/barley $(R)$ & 169 & 283 & 341 \\
\hline
\end{tabular}

Carcase weights and percentage composition for the main effects of diet and slaughter weight are shown in Table 8. There was no significant difference in carcase weight between the comparisons of interest $(\operatorname{Tr} 1 \vee \operatorname{Tr} 2$ and $\operatorname{Tr} 1 \vee \operatorname{Tr} 3)$. There were, of course, highly significant differences between slaughter weights.

TABLE 8

MAIN EFFECTS OF DIET AND SLAUGHTER WEIGHT ON CARCASE TRAITS

\begin{tabular}{|c|c|c|c|c|c|c|c|c|c|}
\hline & \multicolumn{3}{|c|}{$\underline{\text { Diet }}$} & & \multicolumn{5}{|c|}{ Slaughter wt (kg carcase) } \\
\hline & $\begin{array}{l}\text { Sil/ } \\
\text { barley }\end{array}$ & $\begin{array}{l}\text { Con./ } \\
\text { straw }\end{array}$ & $\begin{array}{l}\text { Sil/ } \\
\text { barley (R) }\end{array}$ & & 260 & 300 & 340 & & $\pm S E$ \\
\hline $\begin{array}{l}\text { Carcase } \\
\text { wt }(\mathrm{kg})\end{array}$ & 301.8 & 293.6 & 308.9 & * & 261.8 & 301.3 & 341.3 & $\star \star \star$ & 3.72 \\
\hline$\because$ Meat & 64.5 & 66.4 & 65.7 & $\star$ & 68.6 & 64.6 & 63.5 & $\star \star \star$ & 0.42 \\
\hline Fat & 17.7 & 15.9 & 15.7 & * & 12.4 & 17.2 & 19.6 & $\star \star \star$ & 0.50 \\
\hline Bone & 16.9 & 16.9 & 17.7 & * & 18.0 & 17.4 & 16.1 & $\star \star \star$ & 0.23 \\
\hline $\begin{array}{l}\text { K\&C Fat } \\
(\mathrm{kg})\end{array}$ & 13.1 & 10.0 & 11.0 & $\star \star$ & 8.2 & 10.2 & 15.8 & $\star \star \star$ & 0.58 \\
\hline
\end{tabular}

$\star \star * P<0.001$

There were significant differences in percentage carcase composition between the diets. Cattle fed the silage/barley diet had a lower meat percentage and a higher fat percentage than those fed the concentrates/straw diet. Bone percentage was similar for both treatments. Restricted feeding increased bone percentage, because the animals were older at slaughter, and reduced fat percentage. Increases in slaughter weight decreased meat and bone percentages and increased fat percentage. Animals full fed the silage/barley diet had more kidney and channel fat than those on the other two treatments and also there were increases in kidney and channel fat weights with increasing slaughter weight.

The interaction between diets and slaughter weight on percentages of meat and fat in the carcase are shown in Table 9. At 260,300 and $340 \mathrm{~kg}$ carcase weights, average meat percentages were $68.6,64.5$ and 63.5 respectively, while corresponding values for fat were $12.4,17.2$ and 19.6 respectively. At $260 \mathrm{~kg}$ carcase weight there was no effect of diet on carcase composition. At $300 \mathrm{~kg}$ 
carcase weight there was a small difference, while at $340 \mathrm{~kg}$ the carcases of animals full fed silage/barley had significantly less meat and more fat than either of the other two groups. Therefore, up to $260 \mathrm{~kg}$ carcase weight neither the type of diet nor the level of feeding had any effect on carcase composition, but at higher carcase weights there were effects which became more pronounced as slaughter weight increased.

TABLE 9

INTERACTION OF FEEDING AND SLAUGHTER WEIGHT ON MEAT AND FAT PERCENTAGES

\begin{tabular}{lccccccc}
\hline & \multicolumn{2}{c}{ Meat percentages } & \multicolumn{3}{c}{ Fat percentages } \\
\hline Carcase weight $(\mathrm{kg})$ & 260 & 300 & 340 & 260 & 300 & 340 \\
Silage/barley & 68.8 & 63.5 & 61.3 & 12.5 & 18.5 & 21.9 \\
Con./straw & 69.3 & 65.2 & 64.7 & 12.5 & 16.8 & 18.3 \\
Silage/barley (R) & 67.7 & 64.9 & 64.5 & 12.3 & 16.3 & 18.4 \\
\pm SE & & 0.726 & & & & 0.859 & \\
\hline
\end{tabular}

Since most of the carcase tissue $(260 \mathrm{~kg})$ was deposited before dietary treatments started to exert an influence on composition of the gain, the final composition is not a true reflection of the influence of treatments over the period $260-340 \mathrm{~kg}$. Therefore, the composition of the gain prior to $260 \mathrm{~kg}$ is compared with that for the interval $260-340 \mathrm{~kg}$ carcase weight (Table 10).

TABLE 10

COMPOSITION OF CARCASE GAINS FOR INTERVALS $150-260$ and $260-340 \mathrm{~kg}$ CARCASE WEIGHT

\begin{tabular}{|c|c|c|c|c|}
\hline \multirow[b]{2}{*}{ Carcase gain interval $(\mathrm{kg})$} & \multicolumn{2}{|c|}{ Meat percentage } & \multicolumn{2}{|c|}{ Fat percentage } \\
\hline & $150-260$ & $260-340$ & $150-260$ & $260-340$ \\
\hline Silage/barley & 63.1 & 38.5 & 22.1 & 47.2 \\
\hline Con./straw & 63.9 & 50.8 & 22.4 & 33.6 \\
\hline Silage/barley (R) & 61.5 & 52.8 & 19.4 & 37.2 \\
\hline $\pm S E$ & \multicolumn{2}{|c|}{2.065} & \multicolumn{2}{|c|}{1.484} \\
\hline
\end{tabular}

From the start of the experiment to $260 \mathrm{~kg}$ carcase weight, carcase gain consisted of 63 per cent meat and 22 per cent fat in the two full fed groups and 62 per cent meat and 19 per cent fat in the restricted group. From 260 to $340 \mathrm{~kg}$ carcase, the carcase gain of cattle full fed the silage/barley diet had only 39 per cent meat compared with 51 per cent and 53 per cent for the concentrates/straw and restricted fed treatments respectively. Percentages of fat in the gains were 47,34 and 37 respectively. 


\section{Discussion}

The decline in performance of Friesian steers with increasing weight has been observed in a number of experiments and appears more than can be accounted for by increased maintenance requirements and increased energy content of the gain. It is necessary to establish the reasons for this reduction in performance and ascertain if anything can be done to avert it.

More precise information is needed on the effects and interactions of genotype, sex, plane of nutrition and slaughter weight on carcase composition. This will require large research resources in terms of animals, feed, labour and carcase assessment cost. Complete carcase analysis is expensive but there appears to be no alternative method of obtaining the data that are required to define clearly all the interacting factors which influence the development of a carcase to its final composition.

The finding that diets of similar energy content and which support similar rates of gain produce carcases which differ in composition has interesting nutritional implications. It can be argued that at similar rates of gain increased fat growth (and reduced muscle growth) on one diet compared with another is indicative of amino acid deficiency at tissue level. The crude protein content of the silage/ barley diet was adequate by normal standards and in our experiments there has generally been no worthwhile response to feeding supplementary protein with a view to increasing the amount passing undegraded from the rumen to the small intestine. The animals fed the silage/barley diet retained more of their feed energy and the challenge is to find how the surplus fat energy might be diverted to protein deposition with a consequent increase in meat yield and efficiency.

\section{References}

Broadbent P.J., 1977. A note on the effect of omitting the cereal supplement from a finishing diet offered to weaned single suckled calves. Anim. Prod. 24, 275-278.

Drennan M.J., 1979. Compensatory growth in cattle. I Influence of feeding level during the winter period $9-14$ months of age on subsequent performance and carcass composition. Ir. J. Agric. Res. 18, 131-143.

FLYNN A.V., 1978. The relative importance of different factors in determining the beef production potential of silage. Ph.D. Thesis National University of Ireland, Dublin.

Harte F.J., 1968a. Effects of plane of nutrition on calves for beef production. I Growth rate, feed conversion efficiency, carcass yield and offals. Ir. J. Agric. Res. 7, 137-148.

HARTE F.J., 1968b. Effects of plane of nutrition on calves for beef production. II Carcass composition and distribution of lean meat, fat and bone. Ir. J. Agric. Res. 7, 149-159.

Henrickson R.L., POPE L.S., Hendrickson R.F., 1965. Effects of rate of fattening beef calves on carcass composition. J. Anim. Sci. 24, 507-513.

Kay M., Macdearmid A., Massie R., 1970. Intensive beef production. 11 Replacement of cereals with ground straw. Anim. Prod. 12, 419-424.

KEANE M.G., 1978. Effect of size, ration energy, slaughter weight and breed on carcass traits of steers. M.S. Thesis, Iowa State University, USA.

LeVy D., Holzer Z., Ilian D., 1976. Effect of dietary energy content at different stages of growth on performance of intact male cattle. Anim. Prod. 22, 199-206.

Lawrence T.L., Pearce J., 1964. Some effects of wintering yearling beef cattle on different planes of nutrition. J. Agric. Sci. Camb. 63, 5-34. 
MCCARRICK R.B., 1966. Effect of method of grass conservation and herbage maturity on performance and body composition of beef cattle. Proc. 10th Int. Grassld. Cong., Helsinki, $575-580$.

Prior R.L., Kohlmeier R.H., Cundiff L.V., Dikeman M.E., Crouse J.D., $1977 . \quad$ Influence of dietary energy and protein on growth and carcass composition in different biological types of cattle. J. Anim. Sci. 45, 132-146.

Smith G.M., Crouse J.D., Mantigo R.W., Neer K.L., 1977 . Influence of feeding regime and biological type on growth, composition and palatability of steers. J. Anim. Sci. 45, 236-253.

Swan H., Lamming G.E., 1967. Studies on the nutrition of ruminants. II The effect of level of crude fibre in maize based rations on the carcass composition of Friesian steers. Anim. Prod. 9, 203-208.

Waldman R.C., Tyler W.J., Brungardt V.H., 1971. Changes in the carcass composition of Holstein steers associated with ration energy levels and growth. J. Anim. Sci. 32, 611-619.

Winchester C.F., Howe P.E., 1955. Relative effects of continuous and interrupted growth on beef steers. US Dept. Agric. Bull. 1108. 


\section{Discussion}

\section{Chair : D. LANARI (ltaly)}

T. Griffiths (Ireland). - I would like to put a question to Dr. Cobić concerning his data on nitrogen retention. I did not look at all the data but some of it seemed to be a bit difficult to interpret. I wonder if he would care to comment on it. One occasionally finds data on nitrogen retention in growing animals, which is rather confusing.

T. CoвIĆ (Yugoslavia). - In the first experiment, with the mixed diet, we have got some data which is not easy to explain. For instance, you probably saw that nitrogen balance in the first group was $3.7 \mathrm{~g}$ and the last group was $4.5 \mathrm{~g}$. It just happened and we registered it, but we cannot explain it. We used this apparent digestibility of protein data in order to calculate this relationship between crude protein and digestible protein.

T. Griffiths. - For bulls growing at this rate, did it have any effect at all on carcase lean or carcase protein deposition?

T. Cosic. - We did not investigate that. We only went up to slaughter and we registered the dressing percentage and nothing more. We did not go further.

J.M. Forbes $(U K)$. - I have a question for Dr. Boucqué about his conclusions regarding effets of dietary energy concentration on food intake. First of all in the rat ; it looked to me, in the slide that he showed of Baumgardt's work with rats, that intake did not keep rising with increasing digestible energy concentration, it did reach a plateau. Secondly, his conclusion that some of his cattle kept on eating more digestible energy, even with increasing energy concentration, is rather doubtful. The energy contents of the feeds are expressed as starch equivalents, presumably derived from tables. I want to ask whether the energy value of the feed was measured or simply calculated from the tables ?

Ch. V. Boucque (Belgium). - We only used these diets where the digestibility was determined, as I mentioned in the introduction. We had other experiments too, but we did not use them for these purposes. We used digestibility coefficients obtained at maintenance level with the sheep, of the diet we calculated here.

J.M. Forbes. - So you think that this is a real effect - that there is a positive relationship between the energy concentration of the diet and food intake, in your animals at least, even at fairly high concentrations of energy ?

Ch. V. Boucque. - Yes, I believe that. There are several other authors in the UK who agree. It has been proved that with increasing energy density, intake is higher and gain is higher - and feed efficiency is not worse.

J. L'Estrange (Ireland). - I would like to ask Dr. Boucqué if he found any difference between the sources of energy, in particular between beet pulp and cereal, since the starch equivalents for beet pulp and cereals were probably very similar. Did you find any difference between intake and performance?

Ch. V. Boudque. - I did not compare it because we use very little cereal ; they are too expensive compared to sugar beet pulp. Even in the concentrate with which we supplement roughage diets, we do not use very much cereal, it is mostly beet pulp. Therefore, I cannot give you an exact answer. However, we have some experiments in which we substituted beet pulp for barley (this has already been published) where we obtained a substitution value based on feeding trials and on digestibility trials. The value of beet pulp reached about 90 per cent - 95 per cent of the energy value of barley. It depends on the type of barley that is used ; it was barley with about 4 per cent crude fibre. You can also have barley with 7 per cent -8 per cent crude fibre ; when you use that as reference, you obtain another relative value for your beet pulp. We specified the quality of the barley which was used.

J. L'Estrange. - Is it dried beet pulp alone, or is it molassed ? 
Ch. V. Boucque. - It is not molassed beet pulp. Sugar content was not more than 6 per cent on dry matter basis, indicating no molasses had been added.

H. Bickel (Switzerland). - May I make a general comment. We have heard several results from experiments concerning different intakes in protein and energy. I think we should make an effort to bring these different feeding experiments, and many others, together. By bringing them together I mean we should have a model. We have 4 factors affecting daily liveweight gain and energy conversion ratio. The question is, how to put them together? We have the factor of the gross energy intake. We have the requirement of metabolisable energy for maintenance, the energy value of gain and the partial efficiency of gain. In my opinion there are no other factors. Everything that we are doing can be included in these four factors.

Take as an example the experiment on different proteins by Dr. Cobic. Perhaps there is a possibility that if the animal can put on protein, the " $k g^{6}$ will go down. Or there is the experiment of Dr. Keane where, in his Table 5, he made the hypothesis that perhaps the metabolisable energy requirement for maintenance is going down. That was a hypothesis, but there is some explanation in Table 9 which will explain Table 5. You must analyse one thing after another and put them together in a model. Again, regarding the experiments of Dr. Keane, if you have a restriction period and a compensatory growth somewhere - if you do not have a growth curve which is normal in most intensive beef production systems you will always find that it is possible that energy conversion rate, amount of $\mathrm{ME} / \mathrm{kg}$ liveweight gain, may be lower with the restriction period than with the growth rate of the normal, the control group. It is very difficult to interpret because you do not see anything on the carcase and you are not sure what the energy value of gain is.

As a final point I would like to say that it would be a great help if the dimensions could always be shown on the Tables - MJ $/ \mathrm{kg}, \mathrm{g} / \mathrm{kg}$, etc.

R. Daenicke (Federal Republic of Germany). - Dr. Boucqué, don't you think that the levels you give for your Group 3 would cause problems in practice ? In our country, if we fed such animals with more than 700 starch units/kg dry matter, we would have considerable problems of fat content in the carcase.

Ch. V. Boucoue. - In Group 3 they are White-red, intensively fed animals. The average fat content in the carcase was between 20 and 22 per cent which is quite normal for that breed. It is nearer the Friesian than our White-blue breed. With the White-blue, because they have a liveweight higher by about $100 \mathrm{~kg}$, fatness at slaughter is only between 18 and 20 per cent. However in Belgium this system of baby beef bulls is no longer applied. They are grown on to liveweights of $550 \mathrm{~kg}$.

As for my conclusion for the White-blue animals, in a large number of experiments there is no negative effect of feeding higher intensities to that breed on efficiency of feeding, and on carcase quality. I do not think this conclusion is valid for Friesians or for some other early maturing breeds. There is a distinction between loose-housed animals and tied-up animals. Recently we published an experiment where we compared eight diets in the same building, with the same animals, with the same initial weight, from the same origin, in both tied houses, individually fed, and in loose houses, with straw bedding. It was not the primary purpose to compare them, but we already had them, we got the same differences with a large number of animals - not with the sames diets, but with the same intensity of diets, the same concentrations.

A. Neimann-Sørensen (Denmark). - Dr. Bickel says that we should always try to find a principle in the many experiments that we make. I would like to comment on Dr. Keane's paper where he discusses the influence of the type of diet on carcase composition. I am inclined to think that what you find here is not the diet itself. It is a reflection of the differences in growth which you have between these three diets. Therefore, the fat deposition stage is different in one from the other. It is the same for the straw group because with the straw animals, although they received the same metabolisable energy, they did not grow as fast. Maybe your system overestimates the value of straw. I really believe this, because you have got lower growth. I see this as a principle of that and not as a diet influence on carcase composition.

I would now like to ask Dr. Cobic if the difference in the protein effect, the difference when it is used in a concentrate and a non-concentrate diet, might be that these higher proteins also have an effect on the $\mathrm{pH}$ of the rumen, which may be more favourable to the animal when you have a high concentrate diet. It could be a reflection of that. 
T. Cosić. - I do not think that this is the case. The general situation is that if we feed plenty of maize, there is a danger of getting sub-clinical lactic acid acidosis. In that case we have an unfavourable condition in the rumen. I do think that this is the case ; maybe some other factors are involved.

J. Robelin (France). - I would like to come back to Professor Bickel's comments. It is necessary to know about the different factors which can affect the relationship between gross energy intake and energy deposited in the gain. At the same time I would like to offer an explanation to Dr. Keane on his last experiment. He said that the effect of the level of energy was lower for the first slaughter weight than for the last slaughter weight. This is true, but I would like to make a simple comment on the parameters we use for these measurements. When we measure the effect of level of energy on carcase or body composition, we have a very poor parameter. It is not a sensitive parameter. Dr. Keane has shown clearly in his graphs that a difference of 10 per cent or 5 per cent in the composition of the carcase, or in the composition of the body at the end of the experimental period, means that the difference in terms of lipid deposition was probably three or four times greater. I do not agree that when there is a small difference in the fat percentage in the carcase, you can conclude there is no difference. Statistically, I agree completely, but the problem is to know what is practical and what is statistical. You must take into account the magnitude of the treatment that you have imposed on your animals. In my opinion there is no halt in the effect of level of energy intake on composition of daily gain. I think it is reasonable to say that it is a continuous process. If you see no difference sometimes it is probably due to the difference in the animals at the beginning of the experiment or some other factors.

I have looked at the data from a number of experiments recorded in the literature and I have come to the conclusion that the explanation of the different effects of level of feeding at different ages is that at different ages you have animals which are at different levels of maturity, in the same way that animals of different ages can have approximately the same weight, and therefore the effect on lipid deposition is different.

G. Alderman. - I have a comment, followed by a question. It relates to Dr. Cobic's paper and his comments about the fact that he was finding crude protein levels in diets which seemed to be higher than recommended by digestible crude protein standards. I thought it might be useful to remind you what the ARC protein system would have said about the type of diets he was using. It follows from the relationship that RDP $=7.8 \mathrm{ME}$, that the crude protein content of your diet, in $\mathrm{g} / \mathrm{kg}$, will be $7.8 \frac{\mathrm{M}}{\mathrm{D}}$ (where $\frac{\mathrm{M}}{\mathrm{D}}$ is the energy concentration of a diet), divided by the degradability. If you do that for his first experiment, the $\frac{\mathrm{M}}{\mathrm{D}}$ appears to be $11.6 \mathrm{MJ} / \mathrm{kg}$ and the degradability I have estimated to be about. 73 . The result is that the crude protein content of the diet would be $123 \mathrm{~g} / \mathrm{kg}$. Dr. Čbič was suggesting $128 \mathrm{~g} / \mathrm{kg}$.

If you go into his second experiment, which had a higher energy diet, I estimated the energy content of that to be $12.5 \mathrm{MJ} / \mathrm{kg}$ and the degradability, again, is about 0,7 . That would suggest that we should want $139 \mathrm{~g} / \mathrm{kg}$ of crude protein in the dry matter of the diet. He was suggesting $132 \mathrm{~g} / \mathrm{kg}$.

I was just making the point that the ARC system is suggesting a strict relationship between energy concentration of diets and crude protein at any one degradability. I have done what I can with the little information that we have about degradabilities of things like maize silage and maize and sugar beet pulp, to suggest that I am not surprised that he has come up with these conclusions in relation to the crude protein content of these diets, it is only in the context of the degradability of the diets that he actually used. Moving on to other diets, like those being used by Dr. Keane, what was your estimated metabolisable energy of your silage ?

M.G. KEANE (Ireland). -- We gave it an ME value based on the conventional relation:ship between ME and DOMD, as given in Bulletin 33 .

G. Alderman. - I am hoist with my own petard there.

M.G. Keane. - To answer your question, it was either 9.6 or $9.7 \mathrm{MJ} / \mathrm{kg}$. It was quite a good quality silage.

G. Alderman. - We have many estimations from the Rowett Feed Evaluation Unit, and from our own unit, suggesting that the appropriate value for a silage of the quality you were using would be $11 \mathrm{MJ}$. So your basic supposition that you were comparing iscenergetic 
diets, is not true. I would suggest to you that the reality is that there was between $8-12 \mathrm{MJ}$ extra metabolisable energy in your treatment 1 . In the context of the paper I presented yesterday, if these animals were already depositing all the protein they could manage - which I suspect would have been the case - the only thing they could do was to put down more fat. In the model that I was suggesting yesterday, this is most insensitive in terms of liveweight gain. You would, in fact, pick up exactly what you found, which was a much higher fat content, with no effect on the rate of gain.

K. RoHR (Federal Republic of Germany). - I would also like to make a short comment on the work of Dr. Cobic. My interpretation would differ somewhat from that of Mr. Alderman.

These findings confirm many experiments done with young growing bulls, which show that the protein supply is crucial below a liveweight of $270 \mathrm{~kg}$. To put it simply, below this we need a crude protein content in the ration of about 16 per cent. When you get above this liveweight range there is no problem with protein supply in these animals. At this early stage I do not think you will come up with the right figures using your system.

G. Alderman. - Perhaps I should say that the calculations which I gave were only on the middle period - the $300 \mathrm{~kg}$ liveweight middle period. The ARC system would suggest a need for undegraded protein at the lower liveweight animal, but whether it would have gone critical at the point you are suggesting needs further discussion.

A. Giouseljannis (Greece). - I have two questions for Dr. Boucqué. Firstly, how much is the intake from energy in the rations with ensiled pressed beet pulp as compared to dried beet pulp ? How much is the energy intake or the $\mathrm{kg}$ intake during the fattening period ? Secondly, what do you think about the molasses increasing or decreasing the energy value of dried beet pulp?

Ch. V. Boucque. - Concerning your first question, pressed ensiled beet pulp. We compared it with dried beet pulp, giving it to the same animals for two consecutive years. The intake of dry matter from this kind of ensiled pulp was not lower than with the dried beet pulp. We did the same comparison about 15 years ago with beet pulp ranging from 9 per cent -14 per cent dry matter, compared with dried beet pulp. Then we had a lower dried matter intake of $0.3 \mathrm{~kg}$ dry matter per $100 \mathrm{~kg} \mathrm{LW}$. That was due to the mechanical fill of ruminants - mechanically they stopped eating. We were surprised at the high intake we obtained with the pressed beet pulp. I do not have the figures for the proportion of beet pulp to concentrates, but the concentrate level applied was $0.7-0.75 \mathrm{~kg}$ per $100 \mathrm{~kg} \mathrm{LW}$. That means that it is a maximum of one third of the total dry matter intake of concentrates. Intake of beet pulp increases from a beginning liveweight of $260 \mathrm{~kg}$ to about $600 \mathrm{~kg}$ at the end. A maximum of about $28 \mathrm{~kg}$ per day of the ensiled product was eaten.

Your second question is not easy. Sugar is normally less well utilised than the starch. Adding some molasses to beet pulp does not change the net energy content very much, as shown by Dr. Van Es and others. But when you add a lot of molasses, I think that the efficiency decreases. In practice it is more economic for the farmer to buy molasses and beet pulp separately. 